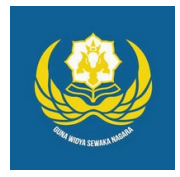

Jurnal Analogi Hukum

Journal Homepage: https://ejournal.warmadewa.ac.id/index.php/analogihukum

\title{
Implementasi Keputusan Presiden Republik Indonesia Tentang Satuan Gugus Tugas Covid 19 PT. Tatamulia Nusantara Indah Cabang Bali
}

\author{
Lia Ayu Lestari*, I Nyoman Putu Budiartha dan Ni Made Puspasutari Ujianti \\ Universitas Warmadewa, Denpasar-Bali, Indonesia \\ *liaayu270294@gmail.com
}

\begin{abstract}
How To Cite:
Lestari, L, A., Budiartha, I, N, P., Ujianti, N, M, P. (2021). Implementasi Keputusan Presiden Republik Indonesia Tentang Satuan Gugus Tugas Covid 19 PT. Tatamulia Nusantara Indah Cabang Bali. Jurnal Analogi Hukum. 3 (2). 188-194. Doi: https://doi.org/10.22225/ ah.3.2.2021.188-194
\end{abstract}

\begin{abstract}
Coronavirus Disease 2019 (COVID-19) is an infectious disease caused by Severe Acute Respiratory Syndrome Coronavirus 2 (SARS-CoV-2). The government is very focused on dealing with this virus. In order to eradicate the spread of this virus, the Government issued Presidential Decree No. 7 of 2020 concerning the Task Force for the Acceleration of Handling CoronaVirus Disease 2019 (Covid 19). PT Tatamulia Nusantara Indah is one of the largest contractor companies in Indonesia. This study aims to determine the implementation and understand what factors are the obstacles and efforts to overcome them in implementing the decision of the President of the Republic of Indonesia regarding the assistance of the Covid 19 task force at the Contracting Company PT Tatamulia Nusantara Indah Bali Branch. This research is empirical legal research. Where the results of this study indicate that the implementation of the Presidential Decree on the Task Force for the Acceleration of Handling Covid 19 and the obstacles faced and countermeasures in implementing the Presidential Decree at PT. Tatamulia Nusantara Indah Bali branch so that it can be carried out as expected.
\end{abstract}

Keywords: covid 19; PT. tatamulia nusantara indah; task force

\begin{abstract}
Abstrak - Coronavirus Disease 2019 (COVID-19) adalah penyakit menular yang disebabkan oleh Severe Acute Respiratory Syndrome Coronavirus 2 (SARS-CoV-2). Pemerintah sangat konsentrasi penanggulangan virus ini. Guna memberantas penyebaran virus ini, Pemerintah mengeluarkan 'Kepres No 7 tahun 2020 tentang Gugus Tugas percepatan penanganan Coronavirus Disease 2019 (Covid 19). PT Tatamulia Nusantara Indah adalah salah satu perusahaan kontraktor terbesar di Indonesia. Penelitian ini bertujuan Untuk mengetahui pelaksanaan dan memahami Faktor-faktor apa sajakah yang menjadi kendala serta upaya untuk menanggulangi dalam mengimplementasikan keputusan Presiden Republik Indonesia tentang satuan gugus tugas Covid 19 di Perusahaan Kontraktor PT Tatamulia Nusantara Indah Cabang Bali. Penelitian ini merupakan penelitian hukum empiris. Dimana hasil penelitian ini menunjukkan bahwa Implementasi Keputusan Presiden tentang Satuan Gugus Tugas Percepatan Penanganan Covid 19 serta kendala yang dihadapi dan upaya penanggulangan dalam mengimplementasikan Keputusan Presiden di PT. Tatamulia Nusantara Indah cabang Bali sehingga dapat terlaksana sebagaimana yang telah diharapkan.
\end{abstract}

Kata kunci: covid 19; PT. tatamulia nusantara indah; gugus tugas

\section{Pendahuluan}

Wabah penyakit virus Corona adalah jenis baru dari coronavirus yang menular ke manusia. Coronavirus merupakan keluarga besar virus yang menyebabkan penyakit pada manusia dan hewan. Virus ini bisa menyerang siapa saja, seperti lansia (golongan usia lanjut), orang dewasa, anak-anak, bayi, termasuk ibu hamil dan ibu menyusui. Infeksi virus Corona disebut COVID-19 dan pertama kali ditemukan di kota Wuhan, China pada akhir Desember 2019. Virus ini menular dengan sangat cepat dan telah menyebar ke hampir semua negara, termasuk 
Indonesia, hanya dalam waktu beberapa bulan. Di Indonesia sendiri, diberlakukan kebijakan Pembatasan Sosial Berskala Besar (PSBB) untuk menekan penyebaran virus ini. Untuk mewujudkan tujuan dari negara kesejahteraan, tugas eksekutif sebagai pelaksana sangat penting karena semakin luasnya lingkup kesejahteraan masyarakat berdasarkan perkembangan zaman. Tugas eksekutif dalam pemerintahan untuk mewujudkan kesejahteraan rakyat tersebut oleh Lemaire disebut sebagai bestuurzorg yaitu penyelenggaraan kesejahteraan umum (Utrecht E, 1957 22-23).

Karena peraturan perundang-undangan tertulis tentunya tidak dapat mengatur segala hal dengan lengkap dan tidak selalu sesuai dengan keadaan terkini. Teori perundangundangan terdiri berdasarkan teori perundangundangan dan rapikan urutan pembentukannya yang relevan menggunakan stufenbau theorie (Atmadja, 2018 151) maka pemerintah juga dapat menggunakan kebijaksanaan bebas, yaitu wewenang untuk mengambil tindakan atas inisiatif sendiri guna menyelesaikan suatu masalah genting atau mendesak dan belum ada ketentuannya dalam peraturan yang dikeluarkan oleh kekuasaan legislatif yang dikenal dengan freies ermessen. Norma itu akan menjadi hukum yang berlaku apabila dikehendaki oleh masyarakat, tertulis, dikeluarkan oleh negara dan memuat perintah, yang menjelaskan bahwa hukum ditaati bukan karena dinilai adil atau baik, namun karena hukum itu tertulis dan disahkan oleh penguasa (Ramadhan, M, C, 2017 53).

Guna memberantas penyebaran virus ini dan memastikan segala prosedur kesehatan dapat dijalankan dengan baik mulai dari pemerintahan sampai dengan masyarakat umum di seluruh rakyat Indonesia, Pemerintah mengeluarkan 'Kepres No 7 tahun 2020 tentang Gugus Tugas percepatan penangan Coronavirus Disease 2019 (Covid 19). Gugus Tugas percepatan Penanganan Covid-19 bertujuan untuk meningkatkan ketahanan nasional di bidang kesehatan mempercepat penanganan COVID19 melalui sinergi antar kementerian/lembaga dan pemerintah daerah. meningkatkan antisipasi perkembangan eskalasi penyebaran COVID-19, meningkatkan sinergi pengambilan kebijakan operasional. meningkatkan kesiapan dan kemampuan dalam mencegah, mendeteksi, dan merespons terhadap Covid-19. Gugus tugas percepatan penanganan Covid-19 terdiri atas pengarah dan pelaksana. Maka Rumusan Masalah dalam penelitian ini adalah, bagaimana Implementasi Keputusan Presiden Republik Indonesia tentang satuan gugus tugas covid 19 di PT Tatamulia Nusantara Indah Cabang Bali dan bagaimana kendala dan upaya penanggulangan dalam mengimplementasikan Keppres di PT Tatamulia Nusantara Indah cabang Bali?

Pentingnya Gugus tugas percepatan penanganan Covid-19 pemerintah bersama dengan Kementerian Ketenagakerjaan mengarahkan agar setiap perusahaan-perusahaan membuat juga Gugus Tugas Covid-19 tidak terkecuali perusahaan yang bergerak dibidang Konstruksi atau kontraktor. Pengertian perusahaan menurut Ebert Dan Griffin adalah satu organisasi yang menghasilkan barang dan jasa untuk mendapatkan laba (Tantri Francis, 2016 3). PT Tatamulia Nusantara Indah adalah salah satu perusahaan kontraktor terbesar di Indonesia. Perusahaan ini mempunyai kantor pusat di Jakarta, dan memiliki kantor cabang di Surabaya dan Bali. Perusahaan PT Tatamulia Nusantara Indah memiliki lebih dari seribu staf dan pekerja mandor yang tersebut di seluruh proyek yang ada di Indonesia. Melihat banyaknya Staf dan pekerja yang dimiliki dan adanya arahan dari Kementerian Ketenagakerjaan terkait pembentukan Gugus Tugas Covid-19, PT Tatamulia Nusantara Indah Membentuk Gugus Tugas Percepatan Covid-19 di Kantor Pusat, Kantor Cabang serta di proyekproyek. Berdasarkan info dari salah satu Manager di PT Tatamulia Nusantara Indah pelaksanaan Gugus Tugas di PT Tatamulia Nusantara Indah memiliki beberapa kesulitan-kesulitan dalam menerapkan pekerjaan yang menjadi tambahan dari Job Description setiap pemangku jabatan yang ditunjuk sebagai Gugus Tugas Covid- 19. Berdasarkan penjelasan diatas peneliti tertarik untuk melakukan penelitian mengenai Implementasi Keputusan Presiden Republik Indonesia Tentang Satuan Gugus Tugas Covid 19 PT. Tatamulia Nusantara Indah Cabang Bali.

\section{Metode}

Metode yang peneliti pakai merupakan penelitian hukum empiris dimana peneliti melakukan wawancara eksklusif ke lapangan buat memperoleh data yang diperlukan, data yang dipakai yaitu data primer yang mana data bersumber menurut penelitian secara eksklusif ke lapangan, data sekunder merupakan data yang bersumber menurut peraturan yang berla$\mathrm{ku}$, literature-literatur. Kemudian ditelaah dan disusun secara sistematis dari persoalan yang akan dibahas (Soekanto, 2007) Teknik pengumpulan data menggunakan pengumpulan data kepustakaan dimana membentuk data sekunder dan teknik penelitian wawancara pada lapangan yang membentuk data primer. Penelitian ini dilakukan di PT Tatamulia Nusantara Indah adalah salah satu perusahaan kontraktor 
terbesar di Indonesia. Perusahaan ini mempunyai kantor pusat di Jakarta, dan memiliki kantor cabang di Surabaya dan Bali. Dimana setelah data terkumpul lalu di Analisa secara kualitatif buat memecahkan perkara yang ada pada lapangan.

\section{Hasil Penelitian dan Pembahasan.}

\section{Implementasi keputusan Presiden Republik Indonesia entang Satuan Gugus Tugas Covid 19 di PT Tatamulia Nusantara Indah Cabang Bali}

PT Tatamulia Nusantara indah Cabang Bali dalam melakukan implementasi Keppres terkait dengan percepatan penanganan Covid 19.Menurut hasil wawancara dengan ketua Satgas Covid-19 cabang Bali Protokol tersebut tertuang dalam 5 bagian penting yaituDivisi Fasilitas dan pencegahan Karyawan yang diberikan tugas di Divisi Fasilitas dan Pencegahan mempunyai fungsi tugas dan tanggung jawab sebagai, penanggung jawab pelaksanaan dan pengawasan semua item fasilitas dan pencegahan pada protokol ini, berkoordinasi dengan seluruh bagian pada gugus tugas dalam penyedian sarana dan prasarana yang diperlukan oleh masing-masing bagian, melakukan perawatan Fasilitas secara berkala.

Fasilitas utama yang harus disediakan adalah thermo Gun, hand sanitizer, tempat cuci tangan, tempat sampah dan alat kebersihan lainnya. Adapun fasilitas yang wajib disiapkan adalah ruang isolasi, obat-obatan $\mathrm{p} 3 \mathrm{k}$ sesuai dengan PERMENAKERTRANS Per.15/MEN/ VIII/2008, Oxygen kaleng 10 buah, $500 \mathrm{ml}$ hand sanitizer, 2 unit tandu, APD Medis Evakuasi, 2 HT, Mobil Evakuasi, bahan dan perlengkapan desinfektan.

Semua karyawan wajib menggunakan masker saat bekerja, bagi pekerja proyek diwajibkan menggunakan kaca mata bening saat bekerja. Fasilitas proyek seperti kantor, gudang, mess staff, bedeng pekerja dan kantin harus dilakukan pembersihan minimal 1 hari sekali. Karyawan dianjurkan untuk melakukan kegiatan berjemur tubuh maksimal 15 menit. Menolak setiap orang luar yang datang tanpa menggunakan masker, dan memiliki suhu tubuh lebih dari 37,3 derajat Celcius. Penanganan khusus akan diberikan bagi pekerja yang memiliki kondisi tertentu seperti tekanan darah tinggi, penyakit jantung, diabetes, penyakit paruparu, Kanker, wanita hamil dan usia diatas 60 tahun.

Bagian Edukasi dan Promosi Karyawan yang diberikan tugas di Divisi Edukasi dan Promosi mempunyai fungsi tugas dan tanggung jawab, menjalankan Protokol Edukasi dan Promosi, sebagai Pusat informasi Covid-19 di Perusahaan

Dalam menjalankan protokol Edukasi dan Promosi perusahaan melakukan Edukasi, sosialisasi dan promosi terhadap protokoler ini dan kebijakan terkait covid 19 lainnya yang dikeluarkan oleh perusahaan dalam meeting mingguan kepada seluruh pekerja. Menggali dan memperbaharui seluruh informasi dari sumber terpercaya terkait kebijakan pemerintah terhadap penanganan pandemi Covid 19. Membuat Flyer poster dan lain sebagainya terkait tata cara menghadapi pandemi Covid 19 dengan baik.

Bagian pengukuran Suhu Tubuh Karyawan yang diberikan tugas di Pengukuran Suhu Tubuh mempunyai fungsi tugas dan tanggung jawab, menyediakan alat dan pemeriksaan suhu tubuh, menegakkan aturan Physical Distancing (Jaga jarak) dan Cuci tangan, melakukan Patroli lapangan untuk random test suhu tubuh. Untuk Menjalankan fungsi ini Deviasi Pengukuran Suhu Tubuh perusahaan menunjuk langsung petugas security karena langsung berada di pintu utama masuk lokasi Perusahaan. Petugas security akan melakukan pemeriksaan suhu tubuh kepada setiap orang. Bagi karyawan dengan suhu tubuh lebih dari 37,3 derajat celcius tidak diperbolehkan memasuki tempat kerja, pekerja atau karyawan diberikan kesempatan untuk istirahat selama 1 jam di ruang isolasi sementara dan akan di cek suhu kembali setelah 1 jam istirahat, apabila setelah menjalani istirahat selama 1 jam dan di ukur suhu kembali masih berada dalam suhu tubuh 37,3 derajat celcius karyawan tidak diperbolehkan untuk masuk kerja dan melakukan Cuti atau berobat ke klinik terdekat dan harus dipulangkan ke rumahnya sendiri/bedeng untuk beristirahat. Hal tersebut tidak akan berpengaruh dengan pendapatan yang bersangkutan apabila disertakan dengan surat dokter yang menyatakan karyawan tersebut memang harus beristirahat. Security akan berkala berkeliling di lokasi proyek ataupun kantor cabang Selain pemeriksaan suhu tubuh secara random Test juga dilakukan pemeriksaan gejala klinis pada tubuh seperti batuk/flu/sesak nafas. Bagian Medis dan Rumah Sakit

Karyawan yang diberikan tugas di Divisi Medis dan Rumah Sakit mempunyai fungsi tugas dan tanggung jawab Melakukan Pemantauan kesehatan dan tanda klinis pekerja, Melakukan tindakan isolasi dan evakuasi, memastikan tersedianya sarana dan prasarana medis 
Petugas Medis dan Rumah sakit dalam struktur organisasi Gugus Tugas Covid-19 memiliki peran yang sangat penting. Petugas bekerjasama dengan security dalam melakukan pemantauan kesehatan dan tanda klinis pekerja. Petugas di divisi ini mempunyai hak melakukan isolasi dan evakuasi di area yang ditentukan. Petugas harus melakukan pengecekan berkala untuk memastikan tersedianya sarana dan prasarana medis di lokasi proyek ataupun kantor. Petugas diwajibkan melakukan kerjasama dengan beberapa rumah sakit yang berada di provinsi bali baik rumah sakit swasta maupun pemerintah guna pelayanan Covid-19.

Bagian Isolasi dan Disinfektan. Ruang isolasi dengan kapasitas 2 pasien wajib disediakan di setiap tempat kerja yang dilengkapi dengan tempat tidur, oxygen, masker, dan pelindung wajah. Penggunaan ruang isolasi hanya bersifat sementara untuk pekerja dengan suhu tubuh 38 derajat celcius sebelum dibawa ke klinik terdekat untuk penanganan lebih lanjut. Penyemprotan desinfektan dilakukan minimal 1 hari sekali pada seluruh fasilitas proyek dan workshop seperti mess, bedeng pekerja, MCK, Kantin, Gudang dll.

\section{Kendala Dan Upaya Penanggulangan Dalam Mengimplementasikan Keppres Di Pt Ta- tamulia Nusantara Indah Cabang Bali}

Adanya beberapa kendala yang dihadapi PT Tatamulia Nusantara indah dalam proses mengimplementasikan Keppres tersebut membuat manajemen harus ekstra bekerja supaya kendala tersebut dapat teratasi. Beberapa upaya yang dilakukan terhadap kendala tersebut membuat Gugus Tugas perusahaan mendapatkan pekerjaan tambahan yang ekstra di masa Pandemi Covid-19. Gugus tugas Covid-19 di PT Tatamulia Nusantara indah ada Staff yang memang sudah bekerja di perusahaan tersebut kemudian diberikan Jobdesk tambahan diluar pekerjaan inti staff tersebut. Upaya-upaya yang dilakukan untuk menanggulangi kendala yang dialami Gugus Tugas Covid-19 PT Tatamulia Nusantara Indah dilakukan dengan cepat.

Upaya menanggulangi Kendala Internal. Upaya Stakeholder PT Tatamulia Nusantara Indah Cabang bali untuk mencari tahu yang mendalam mengenai Keppres tentang Gugus Tugas Covid-19 dengan cara selalu berkoordinasi dengan Kementerian terkait yang menaungi tentang Gugus Tugas Covid-19. Membaca semua literatur yang dikeluarkan pemerintah terkait Covid-19 supaya tidak adanya kesalahan yang mendasar dalam mengartikan setiap putusan dalam Keppres mengenai Gugus Tugas
Covid-19 tersebut. Manajemen PT Tatamulia Nusantara Indah Menunjuk ketua Gugus tugas setiap cabang dan setiap proyek kemudian mengadakan meeting koordinasi untuk penerjemahan maksud dan putusan Keppres tersebut. Jemput bola adalah strategi utama manajemen saat mencari tahu maksud dan putusan kepada jajaran Dinas terkait. Karena Stakeholder PT Tatamulia Nusantara Indah menyadari sibuknya pemerintah dalam hal adanya pandemi Covid-

19 ini karena pandemi ini melanda seluruh Negeri, sehingga siapa yang lebih aktif bertanya atau mendekatkan diri dengan Pemerintah akan lebih cepat mendapat informasi-informasi baru terkait Pandemi Covid 19 ini.

Upaya terhadap permasalahan yang dihadapi dengan adanya penambahan biaya yang harus dikeluarkan dalam periode berjalan. PT Tatamulia Nusantara Indah selalu mengedepankan keselamatan Pekerja diatas segala-galanya, perusahaan meyakini aset terbesar perusahaan adalah karyawan. Oleh karena itu walaupun ada tambahan biaya yang harus dikeluarkan perusahaan tetap di penuhi segala kebutuhan tersebut. Dalam periode Budget kuartal 1 yaitu januari-maret perusahaan membuat budget revisi (R1) untuk menambahkan adanya biaya Pandemi Covid 19. Penambahan biaya yang harus dikeluarkan tersebut membuat pendapatan atau profit perusahaan menjadi berkurang tidak sesuai dengan prediksi yang sudah ditargetkan. Biaya-biaya pemenuhan keperluan terkait dengan Pandemi Covid 19 sepenuhnya menjadi tanggung jawab pihak perusahaan, sehingga karyawan atau pekerja semuanya tidak dibebankan atas adanya biaya tersebut. Gaji karyawan tidak ada yang dipotong akibat adanya biaya yang harus dikeluarkan oleh perusahaan untuk pemenuhan keperluan perusahaan.

Kurangnya kesadaran dari pekerja untuk menjalankan Protokol kesehatan menjadi salah satu masalah terbesar dalam mengimplementasikan Protokol Kesehatan yang harus dijalankan oleh Gugus Tugas Covid 19. Kurangnya pendidikan para pekerja atau buruh-buruh proyek membuat susahnya persuasive guna menjalankan protokol kesehatan, para pekerja berdalih memakai masker, Cuci tangan, mengukur Suhu dan lain sebagainya menjadikan keribetan saat bekerja di Proyek. Protokol kesehatan tersebut bagi mereka pekerja lapangan merasa tidak sesuai karena mereka bekerja panas-panasan apabila diukur suhu kemungkinan akan panas suhu tubuhnya, mereka bekerja pasti berkeringat sehingga masker yang dipakai pasti akan basah, mereka bekerja kotor pasti susah untuk cuci tangan. 
Peran gugus tugas untuk mempersuasif pekerja harus terus dilakukan seperti

Membersihkan tangan secara teratur dengan cuci tangan pakai sabun dan air mengalir selama 40-60 detik atau menggunakan cairan antiseptik berbasis alkohol (hand sanitizer) minimal 20 - 30 detik. Hindari menyentuh mata, hidung dan mulut dengan tangan yang tidak bersih. Menggunakan alat pelindung diri berupa masker yang menutupi hidung dan mulut jika harus keluar rumah atau berinteraksi dengan orang lain yang tidak diketahui status kesehatannya (yang mungkin dapat menularkan COVID-19). Menjaga jarak minimal 1 meter dengan orang lain untuk menghindari terkena droplet dari orang yang yang batuk atau bersin. Jika tidak memungkin melakukan jaga jarak maka dapat dilakukan dengan berbagai rekayasa administrasi dan teknis lainnya. Membatasi diri terhadap interaksi / kontak dengan orang lain yang tidak diketahui status kesehatannya. Saat tiba di rumah setelah bepergian, segera mandi dan berganti pakaian sebelum kontak dengan anggota keluarga di rumah.

Dengan kegiatan persuasive yang harus dilakukan tidak membuat gugus tugas kendor dalam mempersuasif para pekerja atau buruh selalu mengaplikasikan Protokol kesehatan, seperti memberikan masker kain lapis 3 secara gratis sejumlah 4 pcs dengan asumsi sehari 6 jam sekali berganti. Menyediakan tempat cuci tangan dengan jumlah yang cukup sehingga pekerja dapat mencuci tangan tidak berdesakan dan tidak jauh.

Tidak adanya Tenaga Medis dan Klinik Kesehatan di dalam Perusahaan. Dengan tidak adanya tenaga medis dan klinik di dalam Perusahaan terkhusus perusahaan Tatamulia Nusantara Indah cabang Bali membuat manajemen harus segera membuat upaya-upaya mengenai hal ini. Upaya yang dilakukan perusahaan adalah dengan menjalin hubungan kerjasama dengan Rumah Sakit Rujukan Covid-19 dan juga membuat ruang isolasi sementara di kantor pusat ataupun di Proyek-proyek. Ruang Isolasi sementara harus sesuai dengan arahan dinas kesehatan yaitu memiliki ruangan yang bersih, sirkulasi udara yang lancar dan memiliki peralatan kesehatan yang ada di ruangan tersebut. Alat kesehatan yang dimaksud seperti, tempat tidur, tandu, tabung oksigen, baju APD, sarung tangan, masker, hand sanitizer, obat-obatan P3k. Perusahaan memberikan kesempatan ada divisi medis dalam struktur organisasi Gugus Tugas Covid 19 untuk mengikuti pelatihan terkait dengan penanganan kesehatan, pelatihan ini diwajibkan supaya petugas mengerti setidaknya tentang kesehatan secara umum, seperti mengenali gejala karyawan terkena sakit flu, demam, ataupun hilangnya konsentrasi. Pengetahuan secara umum ini sangat penting karena untuk upaya pengambilan keputusan apabila memang ada pekerja yang dimungkinkan terkena Covid 19. Dalam hal upaya screening COvid 19 secara cepat perusahaan menggandeng $\mathrm{Ru}-$ mah sakit yang memang mempunyai pelayanan rapid Test ataupun PCR supaya penanganan bisa dengan cepat dan apabila ada yang terpapar tidak sampai menyebar terlalu jauh dan pekerja yang terpapar dapat segera mendapat penangan.

Upaya menanggulangi Kendala Eksternal Keterbatasan peralatan yang tersedia di tokotoko kesehatan di wilayah Provinsi bali menjadi problem yang sangat penting harus segera diselesaikan. Perusahaan dalam hal ini melalui Ketua-ketua Gugus Tugas yang sudah terbentuk di proyek-proyek segera mencari solusi akan kekurangan peralatan yang ada di Provinsi Bali seperti Thermogun. Alat pengukur suhu tubuh wajib tersedia di pintu masuk perusahaan atau dipegang oleh security yang berjaga karena apabila tamu atau karyawan yang hendak masuk kedalam lingkungan perusahaan namun memiliki suhu tubuh di atas 37,3 derajat celcius diwajibkan jangan memasuki lingkungan perusahaan dalam kata lain alat pengukur suhu tubuh adalah screening awal apakah seseorang diprediksi terjangkit Covid-19 atau bukan. Upaya yang dilakukan perusahaan dalam pengadaan alat pengukur suhu tubuh tersebut yaitu dengan cara membeli alat dalam jumlah banyak kepada supplier yang nantinya akan didistribusikan ke seluruh Cabang yang tersebar di seluruh Indonesia termasuk Cabang Bali. Harga alat pengukur suhu tubuh mengalami kenaikan yang sangat signifikan saat pandemi Covid-19 dikarenakan seluruh perusahaan-perusahaan wajib memiliki alat tersebut. bahkan di wilayah mall, tempat bermain ataupun di beberapa tempat pariwisata.

PT Tatamulia Nusantara Indah adalah perusahaan yang bergerak di bidang jasa konstruksi. Perusahaan selalu mengikuti arahan dari pemerintah terutama saat masa pandemi Covid 19, pekerja di lapangan disarankan untuk menggunakan kacamata proyek yang sudah sesuai dengan standar dari pemerintah. Pentingnya kacamata proyek yang dapat menutupi wilayah mata di masa pandemi menjadikan barang tersebut langka di pasaran. Sama halnya thermogun Kacamata proyek juga menjadi langka dipasaran karena arahan pemerintah untuk para pekerja supaya dapat menjaga bagian mata yang bisa terkena dari percikan dropletdroplet virus tersebut. Cara perusahaan mengatasi permasalahan ini sama halnya thermogun 
perusahaan memesan kepada supplier dalam jumlah banyak untuk memenuhi kebutuhan seluruh karyawan proyek di lapangan. Saat pandemi mulai menyebar di seluruh wilayah indonesia mengharuskan perusahaan segera sigap menggandeng para supplier untuk memenuhi kebutuhan perusahaan, apabila tidak ada kerjasama proses pemenuhan kebutuhan kacamata tidak dapat tercukupi.

Alat pelindung diri dalam masa pandemi sudah ditentukan standarisasi dari pemerintah, mulai dari sarung tangan, faceshield, Masker dan lain sebagainya. Masker sangat berfungsi untuk melindungi diri dari Covid 19 mulai dari percikan- percikan droplet yang keluar dari seseorang dapat tertahan dengan adanya masker. Dengan banyaknya kebutuhan masker saat masa pandemi Covid 19 membuat masker mulai sulit ditemukan di toko-toko kesehatan, adapun ketersedian yang sudah langka harga dipasaran pun meningkat. Masa pandemi Covid-19 menjadikan masker langka ditemukan dipasaran. Beberapa masker yang dijumpai dipasaran mengalami kenaikan harga yang sangat signifikan mencapai $500 \%$ bahkan lebih dari harga awal dipasaran. Maka cara perusahaan mengatasi masalah tersebut dengan bekerja sama dengan para konveksi yang ada untuk membuat masker kain, masker kain dipakai sesuai arahan atau anjuran dari dinas kesehatan. Masker kain yang diproduksi oleh PT Tatamulia Nusantara Indah sesuai dengan anjuran Dinas Kesehatan yaitu 3 lapis. Dan pemakaianya pun maksimal 6 jam sekali harus ganti, jadi setiap karyawan proyek mendapatkan 5 masker kain setiap orangnya agar pemakaiannya sesuai dengan anjuran dari dinas kesehatan. Kerjasama dengan pabrik konveksi dilakukan untuk mempercepat pengadaan Masker para pekerja supaya para pekerja dapat menjalankan protokol kesehatan dengan cepat dan tepat sehingga terhindar dari Covid 19.

Rumah sakit menjadi tempat yang sangat penting di masa pandemi Covid 19. Peran rumah sakit menjadi sangat vital dalam penanganan wabah Covid 19, rumah sakit yang ada di seluruh Indonesia haruslah memiliki standar operasional yang sama mulai dari rumah sakit pemerintah sampai dengan rumah sakit swasta. Standar yang sama ini haruslah dapat membantu dalam penanganan setiap pasien Covid 19 ini. Dalam masa pandemi Covid 19 di masa-masa awal terlihat masih sedikit rumah sakit yang masuk kedalam rumah sakit rujukan Covid 19. Minimnya rumah sakit rujukan pasien Covid-19 pada awal masa pandemi melanda di Provinsi Bali mengharuskan PT Tatamulia Nusantara Indah cabang Bali harus segera menjalin kerjasama dengan Rumah
Sakit yang memang ditunjuk oleh dinas kesehatan sebagai rumah sakit Rujukan di Provinsi Bali. Kerjasama di buat supaya karyawan yang mengalami gejala terjangkit Covid-19 atau bahkan sudah terjangkit dengan Covid-19 dapat segera dilayani atau dilakukan perawatan yang intensif. Contoh beberapa rumah sakit rujukan yang menjalin kerjasama PT Tatamulia Nusantara Indah cabang Bali adalah rumah sakit Bali Mandara, Rumah sakit Surya Husadha, Rumah sakit bhakti rahayu, dan Klinik Kenak Medika Ubud. Rumah sakit tersebut siap membantu memberikan pelayanan yang intensif apabila memang ada gejala terpapar Covid 19. Pelayanan mulai dari Rapid Test, PCR tes dan bahkan pelayanan rawat inap bagi pekerja yang terpapar serta adanya gejala atau penyakit bawaan.

Dalam pandemi Covid 19 yang melanda seluruh wilayah Indonesia diperlukan sosialisasi dari dinas terkait untuk mengerti betul bagaimana mengupayakan cara menanggulangi wabah ini, Upaya yang dilakukan Gugus Tugas Covid19 di PT Tatamulia Nusantara Indah dalam menghadapi kendala tersebut adalah dengan cara jemput bola. Ketua Gugus Tugas Covid-19 menyadari bahwa kurangnya tenaga di kementerian terkait untuk dapat menjangkau seluruh perusahaan-perusahaan yang tersebar di Provinsi Bali .Dengan terus jemput bola atau bertanya kepada dinas terkait dalam proses penanggulangan pandemi Covid 19 PT Tatamulia Nusantara Indah berharap tidak ada informasi yang tertinggal atau kebijakan-kebijakan dari pemerintah yang tidak diketahui oleh perusahaan.

\section{Simpulan}

PT Tatamulia Nusantara indah Cabang Bali dalam melakukan implementasi Keppres terkait dengan percepatan penanganan Covid 19 tertuang dalam Protokol New Normal Pandemi Covid 19 yang disahkan oleh pemimpin tertinggi dalam hal ini Presiden Direktur. Protokol tersebut tertuang dalam 5 bagian penting yaitu Divisi Fasilitas dan pencegahan. Dalam proses pemenuhan fasilitas dan pencegahan perusahaan bekerjasama dengan supplier-suplier supaya pemenuhan kebutuhan dapat terlaksana. Bagian Edukasi dan Promosi Bagian pengukuran Suhu Tubuh. Bagi karyawan dengan suhu tubuh lebih dari 37,3 derajat celcius tidak diperbolehkan memasuki tempat kerja, Karyawan diminta untuk masuk dan beristirahat selama satu jam dan kemudian akan dilakukan tes Suhu Tubuh ulang, apabila masih di angka 37,3 derajat Celcius karyawan harus dipulangkan ke rumahnya sendiri/bedeng untuk beristirahat dan 
dianggap masuk kerja atau ijin sakit apabila ada membawa surat sakit dari klinik atau dokter. Bagian Medis dan Rumah Sakit Bagian Isolasi dan Disinfektan

Dalam Mengimplementasikan Keppres tentang Satgas Covid-19 ini PT Tatamulia Nusantara Indah Cabang Bali memiliki beberapa kendala dari awal saat akan mengimplementasikan Keppres ini sampai dengan berjalannya proses implementasi, Kendala yang dihadapi dibagi dalam 2 kategori yaitu kendala Internal meliputi (keterbatasan pengetahuan dari Stakeholder dan Pekerja tentang Keppres Satgas Covid19 di awal Pandemi, Adanya penambahan biaya yang harus dikeluarkan dalam periode berjalan, Kurangnya Kesadaran dari Pekerja untuk menjalankan Protokol Kesehatan, Tidak memiliki tenaga medis atau Klinik di perusahaan). Kendala Eksternal meliputi (Keterbatasan peralatan kesehatan yang tersedia di toko-toko kesehatan di Bali, Minimnya Rumah Sakit yang menjadi rujukan penderita Covid-19, Kurangnya Sosialisasi dari Dinas terkait).

\section{Daftar Pustaka}

Atmadja, I, D, G., Budiartha, I N, P. (2018). Teori-Teori Hukum. Malang: Setra Press.

Francis, T. (2016). Pengantar Bisnis. Jakarta: PT Raja Grafindo Persada.

Ramadhan, M, C. (2017). Pengaruh Aliran Positivisme Dalam Kebijakan Pembentukan Peraturan Perundang-undangan di Indonesia. Jakarta: Warta Dharmawangsa.

Soekanto, S. (2007). Pengantar Penelitian Hukum, Universitas Indonesia. Jakarta.

Utrecht, E. (1957). Pengantar Hukum Tata Usaha Negara Indonesia. Jakarta: NV Balai Buku Indonesia. 